Bond University ePublications@bond

Sports Law eJournal

Faculty of Law

2-13-2007

\title{
Sports Marketing in China : an IP perspective
}

Rebecca Ordish

Follow this and additional works at: http://epublications.bond.edu.au/slej

Part of the Entertainment, Arts, and Sports Law Commons, and the Marketing Law Commons

\section{Recommended Citation}

Rebecca Ordish. (2007) "Sports Marketing in China : an IP perspective" ,, .

http://epublications.bond.edu.au/slej/3

This Journal Article is brought to you by the Faculty of Law at ePublications@bond. It has been accepted for inclusion in Sports Law eJournal by an authorized administrator of ePublications@bond. For more information, please contact Bond University's Repository Coordinator. 


\title{
Sports Marketing in China : an IP perspective
}

\begin{abstract}
[Extract] Given the increasing popularity of sports among Chinese consumers and China's hosting of a number of international sporting events and with the Beijing Olympics just around the corner now giving China centre stage on the sports front, it is no wonder that brand owners are seeking out sports marketing opportunities there. But brand owners must take note of the risks, particularly concerning intellectual property (IP) and brand management. Indeed, China's sports marketing environment is relatively new, and many players are inexperienced in the complexities of sponsorship arrangements. Moreover, the PRC regulatory environment is still developing, and IP rights remain difficult to enforce. Only companies that manage risks carefully will protect their brands and get the most from their sponsorship marketing dollars.
\end{abstract}

\section{Keywords}

intellectual property, sports, marketing, china, sponsorship

\section{Disciplines}

Entertainment, Arts, and Sports Law | Marketing Law

\section{Publication Details}

An earlier version of this article was first published in China Business Review in November/ December 2005. 


\section{SPORTS MARKETING IN CHINA - AN IP PERSPECTIVE}

\section{By Rebecca Ordish ${ }^{1}$}

\section{Date of Publication: 13 February 2007}

Yao Ming, a household name in China and the United States, has had an impressive career playing basketball in the Chinese Basketball Association (CBA) and for the Houston Rockets. In 2003, Yao filed suit against the Coca-Cola Co in China for using his portrait, which was displayed together with the portraits of two other CBA players on commemorative cans. Coca-Cola argued that it had an agreement with the agent of the Chinese national men's basketball team, Chinese Sports Management Co, for sponsorship of the national team to which Yao belonged and therefore had the right to use Yao's image as part of the team. The case, which caused much debate among legal professionals, settled prior to a court decision. Coca-Cola agreed in the settlement to apologise publicly to Yao. ${ }^{1}$

From VW and SNICKERS chocolate sponsoring the Beijing Olympics to Royal \& Sun Alliance sponsoring fun runs, to ANZ sponsoring the Cricket Sixes in Shanghai, many international companies have already taken the plunge into sports marketing in China and are learning its rewards and risks. For example, Siemens AG sponsors the Chinese National Football Team. The company extended its sponsorship to the China Football Association's Super League in 2004, but terminated the relationship in early 2005 because of problems during the Super League's first season. (The season had ended in a near-boycott by sports clubs following widespread allegations of corruption and match fixing. $)^{2}$

Interest is also increasing from international sports clubs wanting to engage in sports related activities in China. The NBA has sent teams to China for friendly matches arising from the popularity of Yao Ming in the United States. Chelsea Football Club, aware of the potential for seeking players from China in the future, has recently announced an agreement with the China Football Association to conduct grassroots training activities for soccer in China and to run a Chinese language version of their website. ${ }^{3}$ The Yankees have also recently announced similar arrangements with the China Baseball Association.

Given the increasing popularity of sports among Chinese consumers and China's hosting of a number of international sporting events and with the Beijing Olympics just around the corner now giving China centre stage on the sports front, it is no wonder that brand owners are seeking out sports marketing opportunities there. But brand owners must take note of the risks, particularly concerning intellectual property (IP) and brand management. Indeed, China's sports marketing environment is relatively new, and many players are inexperienced in the complexities of sponsorship arrangements. Moreover, the PRC regulatory environment is still developing, and IP

\footnotetext{
${ }^{1}$ Rebecca Ordish is IP Counsel - Greater China for Diageo. She is currently writing a practical guide to IP protection and commercialisation in China. An earlier version of this article was first published in China Business Review in November/ December 2005.
} 
rights remain difficult to enforce. Only companies that manage risks carefully will protect their brands and get the most from their sponsorship marketing dollars.

\section{Protect IP rights}

The first step to a successful sports sponsorship deal in China is to identify the rights in the deal and to ensure that they are adequately protected. Copyright and design rights will protect certain IP elements, such as logos, athletes' uniforms, and stadium designs. But it is also particularly important to protect trade mark, domain name and portrait rights in sports sponsorship arrangements.

\section{Trade marks: the strongest protection}

A registered trade mark is essential to protect brand rights in China; the more elements a company registers as a trade mark, the stronger the company's enforcement options will be and the greater the value of its sponsorship in China. Fortunately, China's enforcement mechanisms for registered trade marks are becoming increasingly effective, and public trust in civil litigation is growing. In 1998, fewer than 4,000 trade markrelated IP infringement cases were filed with Chinese courts. In 2006, the Chinese courts heard 14,219 civil cases of IP violations, up almost 6\% from 2005.4

Though China recognises trade marks not registered in China, the protection is limited to those classified as 'well-known trade marks'. As of October 2006, China recognised 187 well-known trade marks including 28 foreign trade marks.

China maintains a 'first-to-file' trade mark registration system, which makes it crucial for companies to file trade mark applications early. Companies should also consider whether to register a Chinese version of their trade mark. Pfizer Inc learned this lesson the hard way when the Chinese pharmaceutical company Shenyang Feilong Pharmaceutical Co Ltd, registered its own version of Pfizer's brand Viagra, Weige, in China. The Chinese company's registration cost Pfizer a significant amount of money (in legal fees while trying to recover the registration and in lost sales) and has made it harder for Pfizer to expand distribution of its Viagra brand in China. When activating sponsorship rights, it is important to localise the promotion for Chinese consumers. HP did a good job of this with their sponsorship of the BMW Williams F1 team. For the Chinese race in Shanghai in 2005, the team vehicles included the Chinese version of the company name, 'Hui Pu', alongside the English name to maximise the sponsorship in China.

To protect the value of their investment, sports sponsors should ensure that the rights holders of the sporting event have registered the relevant trade marks in China. In addition to registering more typical items, such as event names, team logos, and event logos, it is possible to trade mark some less-common items in China for greater protection. For example, the underwear company Beijing Dani'aier Clothing Co Ltd, registered the competitor number of a famous Chinese hurdler, Liu Xiang, '1363' for the Athens 2004 Olympics. Also, China allows registration of athletes' names as trade marks, which is impossible in many countries. Some requirements for this right were established when the grandson of the famous early twentieth-century Chinese author, Lu Xun, tried, but failed, to register his name as a trade mark covering wine. ${ }^{5}$ 
The initial requirements to register a person's name as a trade mark in China are basic: the person must give his or her consent, and the name must be distinctive as a trade mark. But, in the past (such as in the $2001 \mathrm{Lu}$ Xun case), the State Trade Mark Office has also tried to keep the names of famous individuals available for public use; the government evidently believes that when a person is held in high moral, historical, or cultural esteem, that person's name is owned by society and should be available for public use. However, currently applications for lesser known athletes' names are being accepted for registration; for example Lin Dan, China's world top-rating badminton player, found recently that his name was already registered for health products when he tried to register it as a trade mark. A Chinese entrepreneur also recently tried to register Yao Ming's name as a trade made covering sanitary pads!

\section{Portrait rights protect the value of an image}

Internationally-known Chinese athletes are quickly becoming the new pop stars of China. In 2005, the Laureus World Sports Awards named Liu Xiang its Newcomer of the Year, an award fellow compatriot Yao Ming won in 2003.

Unlike other jurisdictions, such as the US, PRC law provides for a portrait right rather than a separate right of publicity; use of a citizen's portrait in China for profit without consent is prohibited. In Australia, celebrities have to rely on passing off or actions under the Trade Practices Act to protect their image. Chinese athletes are increasingly aware of the value of their portrait rights, and several athletes have recently sought to protect their commercial value.

The Yao portrait case demonstrates that sport sponsors should confirm that they have the rights they are paying for and that the sports organisations with which they negotiate have the relevant rights regarding the athletes. In the future, sponsorship of individual athletes may well conflict with team sponsorship. When sponsoring a team, sponsors should ensure that their agreement restricts individual athletes from entering into conflicting agreements with the sponsors' competitors.

The portrait right is not absolute. The Haidian District People's Court in Beijing considered its limitations in a recent case involving an image of Liu Xiang winning his gold medal at the Athens Olympics. The photo was placed on the front page of a newspaper above an advertisement for a local department store. Liu believed that the image's placement implied that he had endorsed the department store and therefore infringed his rights. The court divided portraits into two categories: a portrait that is independent of any special significant public event; and a portrait that is associated with a special significant public event. It decided that the portrait right for the former is absolute and the portrait right for the latter is subject to limitations. The court held that Liu's right of portrait, when associated with a major public event such as the Olympics, was subject to a fair use exception. In that case, the photo was used as the cover image for a newspaper article on major events in 2004, and the newspaper had obtained a license from Getty Images Inc to reprint the image for news reporting purposes. The court thus ruled in the newspaper's favour. ${ }^{6}$

Although this case was overruled on appeal (on interpretation of the use of the article rather than the law), ${ }^{7}$ it was significant for a number of reasons. First, it underlines athletes' expanding awareness of their portrait rights and the commercial value associated with them for sponsorship opportunities. Second, it shows the court's 
awareness of the importance of this issue. It seems likely that the district court sought input from the Supreme People's Court, as the judgment was thorough, well argued, and carefully established the reasoning for the decision and the boundaries of the portrait right. The district court likely realised that in the lead-up to the Beijing 2008 Olympics, more athlete sponsorship arrangements will be negotiated, and more companies will seek to benefit from athletes' fame. A small restaurant owner sought legal advice recently, for example, because he wanted to celebrate Liu Xiang's latest hurdling win with a special offer to his customers. He wanted to promote the special offer with a banner and a photo of the famous hurdler. He was told that, although he could use Liu Xiang's name in a promotion in celebration of his win, he could not use the image as it would infringe Liu Xiang's portrait rights.

\section{Domain names - the often forgotten rights}

It is critical to register all appropriate domain names as soon as possible once sponsorship has been agreed. Domain names are quick and easy to register and so often fall prey to cyber squatters who get in first. The domain name liuxiangvisa.net' was registered by a cyber squatter following the announcement of Visa's sponsorship of the famous athlete. The name was then auctioned and sold for over 190,000 RMB (over A $\$ 31,600)$. Although it is possible to recover the domain names in some cases if bad faith can be proved (such as auctioning the domain name), it is advisable to register all combinations of words in a domain name before announcement of the sponsorship.

\section{The sponsorship agreement: a critical tool}

The sponsorship agreement is important for any sports sponsorship arrangement to succeed. In China, however, the role of the agreement is even more crucial. As sports marketing and event management are relatively new concepts in China, it is necessary to have a clear and detailed contract that specifies the parties' rights and obligations. PRC authorities are often unaccustomed to the types of rights and support international sponsors expect (for example, where logos should be placed at an event, how the bundle of rights' is divided among sponsors, and how rights holders should promote official sponsors). Many of the sponsorship strategies and agreements that are tried and tested overseas will require tweaking for successful use in China. Though each sponsorship will vary, sponsors should check a few key issues:

\section{(1) Confirm the scope of your rights as a sponsor}

Modern sports sponsorships are complex, as brand owners fight for sponsorships and rights holders divide sponsorships into smaller and smaller pieces. Sponsors also try to squeeze as much value as possible from their sponsorship dollar through innovative logo placements. Problems with, for example, logo placement and co-marketing are likely to arise, particularly with venue operators and broadcasters. So, it is important for sponsors to include these issues in the agreement, to strengthen their future bargaining position. Companies should not assume that sports sponsorship in China will be as sophisticated as sponsorship overseas. In some countries with more developed sports sponsorship markets, vague language, such as 'right to logo placement at the event', can work to a sponsor's advantage, as the sponsor bargains for greater coverage. In China, however, it is more likely to lead to frustration, as the expectation gap between the sponsor and the rights holder will often be wide. 


\section{(2) Keep your sponsorship rights exclusive}

The core value of a sponsorship is derived from the extent of its exclusivity. This needs to be carefully negotiated; companies should make sure their sponsorship agreement contains no 'gaps' that could allow competitors to reduce the value of the sponsorship through ambush marketing (when competitors of official sponsors associate their brand with the event without authorisation). One of the best ways to prevent ambush marketing is through a strong sponsorship agreement that expressly covers the company's expectations of the rights holder and that addresses all appropriate sponsorship rights. Sponsors must not leave a form of media out of their agreement such as the internet, which is commonly forgotten - and risk finding their competitor sponsoring the official website. Examples of clever ambush marketing can be found in many past sporting events. For example, for the 2000 Sydney Olympics, which was officially sponsored by the now-defunct Ansett Australia, Qantas Airways Ltd launched an intensive advertising campaign that featured a number of Olympic athletes. And Adidas-Solomon AG's official sponsorship of the 2002 World Cup was ambushed by Nike Corp's sponsorship of the Brazilian team, whose members all wore Nike uniforms. In China, Coca Cola faced ambush in their sponsorship of the first F1 race in Shanghai by Pepsi. Coca Cola was the official sponsor within the race track grounds. However, there was a KFC outlet just across the boundary which was selling Pepsi and a lot of the competing cola made it over the fence into the grounds. The next year a $5 \mathrm{~km}$ radius from the venue was included in the sponsorship agreement, to avoid a repeat issue.

Compared with their Chinese counterparts, many international sponsors have a distinct advantage: they understand how to get the most out of their sports sponsorships. For example, they do not merely slap a logo on a uniform, but create noise around their brands through associated events and marketing campaigns. On the other hand, Chinese companies' marketing strategies are becoming increasingly sophisticated, and more domestic companies are sponsoring overseas teams and athletes. For example, Haier Group Co sponsored the Australian professional basketball team in 2004 and many high-profile Chinese firms, such as Lenovo Group Ltd. and Haier, will sponsor the 2008 Olympics.

One of the risks associated with sponsorship in China is ambush marketing by Chinese companies that use their relationships with authorities to target foreign brand owners' sponsorship of events. To minimise this risk, it is important to ensure that the sponsor address all appropriate rights and confirm in the agreement that the rights holder is obligated to prevent ambush marketing.

\section{(3) Confirm that the rights holder will also protect IP}

Unfortunately, a boost in a sponsor brand's global exposure and growth in China's sporting industry make infringement of related IP rights ever more likely. Brand owners must take steps to protect their own brands and must expressly place an obligation on the rights holder to protect the value of the IP in which the brand owner is investing. The rights holder should also assist and control infringements in a fast, effective manner (for example, by providing evidence of their rights to PRC authorities). The sponsorship agreement should expressly cover these expectations.

Adidas and Nike have faced significant infringement issues in China as a result of their success. In 2006, Hangzhou Customs seized over 30,000 counterfeit sports shoes in 22 
separate cases and the majority of items seized for counterfeit Adidas and Nike products. Adidas and Nike run active training programs with Customs officials to increase the products being seized which is a very successful strategy available to all brand owners.

\section{Leaving an Olympic IP legacy}

The Beijing Olympic Committee (BOCOG) is eager to leave an 'IP Legacy' from the Olympics in which China is stronger in its intellectual property awareness, protection and enforcement. It has introduced strong penalties for infringement of the Olympics name and logos as well as the Olympic Mascots. ${ }^{8}$ It has also sought support from the public in reporting infringements of the Olympic IP. So far, this approach has been working with consumers quick to report sightings of counterfeit Olympic Mascots to BOCOG's team. Meng Niu, a well-known dairy company in China, was recently warned by BOCOG not to use an image for a promotion which was claimed to be similar to the five Olympic rings logo. Although sightings do exist, there is far less infringement in the market at this stage of Olympic IP. Some claim this is due to respect for the Olympics. Others claim, somewhat sceptically, that the government is simply doing a more effective job of stopping these infringements. Either way, it will be interesting to see whether BOCOG is able to achieve its goal and leave China a more IP aware country after the Olympians move on.

\section{Learn the risks, aim for the rewards}

As the disposable income of China's burgeoning middle class rises, so does the power of sports in China. Recent years have seen a significant shift in the sophistication and prestige of China's sporting events. Shanghai first hosted the Formula 1 Grand Prix in 2004, with the event continuing to grow every year since. In 2005, the same Shanghai track hosted the Moto GP World Championship and the V8 Supercars from Australia. The Tennis Masters Cup, featuring the world's top eight male tennis players, was hosted in Shanghai in 2005 and 2006. Shanghai also played host to the Volkswagen 48th World Table Tennis Championships in May 2005.

The opportunities are undeniable, but sports sponsors should be careful as they enter the Chinese market. Event management is still in its early stages in China, and local sports marketing skills are still thin on the ground. It is important for companies to plan carefully and to ensure that the investment they are making is protected, particularly from an IP perspective. Sports marketing is, after all, about the power of brands - the combined power of the sponsor's brand and the rights holder's brand to deliver value to both sides of the table.

\section{Don't forget the State}

Negotiating sponsorship with a team or with athletes in China raises a unique challenge. Because nearly all athletes in China are supported by state-run sports organizations, the state has the right to manage athletes' commercial rights. Tian Liang, the 2000 and 2004 Olympic diving champion, and a Hong Kong entertainment group learned this lesson the hard way. After entering into a sponsorship arrangement with the Emperor Entertainment Group without state approval in early 2005, Tian was expelled from the Chinese National Diving Team and placed on a provincial squad. ${ }^{9}$ Not only were Tian's hopes of future Olympic glory shattered, but the sponsor lost its sponsorship and the money it had already paid under its agreement with the 
athlete. Sponsors should confirm that the relevant national or local authority, which is determined by the player's team, has approved the sponsorship arrangement and that the athlete has given his or her approval for use of the portrait. Companies should expect sports sponsorship agreements to involve the sponsor, the athlete, and the state. ${ }^{2}$

${ }^{2}$ For more information on Intellectual Property Protection in China, the following resources contain some information:

China's 2005 White Paper on Intellectual Property Protection - $\underline{\text { http://www.china.org.cn/e- }}$ white/20050421/

The State Administration of Industry and Commerce's Outline of Intellectual Property Rights Protection Actions for 2006-2007 - http:// sbj.saic.gov.cn/ english/show.asp?id=462\&bm=sbyw

The US Embassy has a useful Toolkit in Intellectual Property Rights in China - $\underline{\mathrm{htt}} \mathrm{p}$ /// beijing.usembassychina.org.cn/ipr.html

The State Intellectual Property Office's Website - http:// www.sipo.gov.cn/sipo English/default.htm

The Ministry of Commerce's IPR Working Group website - http:// www.ipr.gov.cn/ en/index.shtml . $20 / 02 / 2007$

1 See, eg, <http:/ english.peopledaily.com.cn/200310/17/ eng20031017 126266.shtml> at 4 February 2007.

${ }^{2}$ See, eg, <http://english.peopledaily.com.cn/200502/01/eng20050201 172508.html > at 4 February 2007.

${ }^{3}$ See, eg, <http://english.peopledaily.com.cn/200502/01/eng20050201 172508.html>at 4 February 2007.

$4<\mathrm{http}$ :/ english.peopledaily.com.cn/200701/ 18/ eng20070118 342537.html > at 4 February 2007.

${ }_{5} \mathrm{See}$, eg, <http:// www.gotlinks.com/ earticles/articles/91067-registration-of-personal-names-in-the-prc.html >at 4

February 2007.

${ }^{6}$ See, eg, <http:// english.peopledaily.com.cn/200505/26/eng20050526 186905.html>at 4 February 2007.

7 See, eg, <http:// www.chinadaily.com.cn/english/ doc/2005-12/16/ content_503978.htm at 4 February 2007.

${ }^{8}$ See BOCOG's website for more details <http:// en.beijing2008.cn/ 87/67/ column211716787.shtml> at 4 February 2007.

${ }_{9}^{9}$ See, eg, <http:// www.china.org.cn/ english/sports/ 123815.htm at 4 February 2007. 